\title{
Selectivity of pre-emergent herbicides in bird's-foot trefoil crops
}

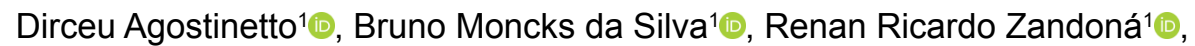 \\ Roberto Avila Neto ${ }^{2}$, Diego Severo Fraga ${ }^{1} \oplus$, Queli Ruchel ${ }^{1}[0$

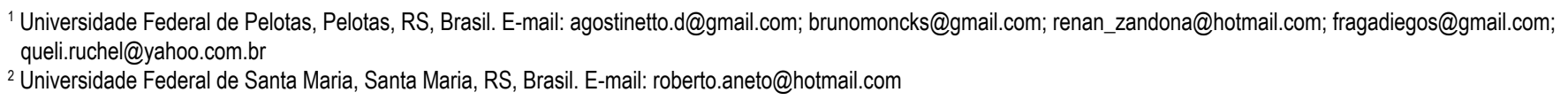

ABSTRACT: Competition with weeds and lack of selective herbicides registered for bird's-foot trefoil crops affect their development and limit productivity. Therefore, this study aimed at evaluating selectivity of pre-emergent herbicides in bird's-foot trefoil crops. Experiments were carried out in a greenhouse and on a field where the following herbicides were evaluated and compared with the control: imazethapyr, diclosulam, flumetsulam, metribuzin, s-metolachlor, sulfentrazone, clomazone and isoxaflutole. Regarding variables under evaluation, phytotoxicity (PHYTO), plant stature, dry mass of the aerial part (DMAP) and dry mass of roots (DMR) were evaluated in the greenhouse, while plant population, PHYTO and DMAP were assessed on the field. The criterion to determine selectivity were: PHYTO below $15 \%$ and not reducing the plant population nor morphological variables, by comparison with the control. The variables were negatively affected by the herbicides clomazone, metribuzin, isoxaflutole, diclosulam, s-metolachlor, in which the crop population was reduced in $98,92,83,63,48$ and $22 \%$, respectively. Following the criteria, only the herbicide sulfentrazone as a pre-emergente is selective to bird's-foot trefoil crop (cultivar 'São Gabriel').

Key words: chemical control; efficiency; Lotus corniculatus; management

\section{Seletividade de herbicidas pré-emergentes para a cultura do cornichão}

RESUMO: A competição com plantas daninhas e a falta de herbicidas seletivos registrados para a cultura do cornichão comprometem o desenvolvimento e limitam a produtividade da cultura. Diante disso, objetivou-se avaliar a seletividade de herbicidas pré-emergentes à cultura do cornichão. Foram conduzidos experimentos em casa de vegetação e campo, avaliandose os herbicidas imazethapyr, diclosulam, flumetsulam, metribuzin, s-metolachlor, sulfentrazone, clomazone e isoxaflutole, mais uma testemunha sem aplicação. As variáveis avaliadas foram fitotoxicidade (FITO), estatura de plantas, massa seca da parte aérea (MSPA) e de raiz (MSSR), em casa de vegetação; e, população de plantas, FITO e MSPA no campo. Os critérios para determinar a seletividade foram: FITO inferior a $15 \%$ e, a não redução da população de plantas e das variáveis morfológicas comparativamente a testemunha. As variáveis foram afetadas negativamente pelos herbicidas clomazone, metribuzin, isoxaflutole, diclosulam, s-metolachlor, que reduziram a população de plantas $98,92,83,63,48$ e 22\%, respectivamente. Com base nos critérios apenas o herbicida sulfentrazone aplicados em pré-emergência é seletivo para a cultura do cornichão, cultivar São Gabriel.

Palavras-chave: controle químico; eficaz; Lotus corniculatus; manejo 


\section{Introduction}

Brazil is the world's second largest producer and the largest beef exporter, since it produces about 9.6 million tons per year (FAO, 2020). The country's cattle rearing is based on natural and cultivated pasture (Ferraz \& Felício, 2010). Total pasture area (both natural and cultivated) is about 159 million hectares, it predominates in Brazil's Central-West region (35\% - 7\% natural and $28 \%$ cultivated pasture), while its South region has the lowest one ( $9 \%$ - 5\% natural and 4\% cultivated pasture) (IBGE, 2019).

The use of cultivated pasture has been increasing, not only because it is an alternative to face periods in which there is shortage of food (Flores et al., 2008), but also because it is one of the most profitable and practical forms of producing and feeding cattle (Ferraz \& Felício, 2010). In this context, the genus Lotus has been of great agricultural interest to be used as a forage species.

Considering all species that constitute the genus, $L$. corniculatus L. (bird's-foot trefoil) is broadly distributed in pasture due to its outstanding capacity to adapt to different edaphoclimatic conditions (Ayala \& Carámbula, 2009) and its quality as forage, since it has up to $24 \%$ crude protein and $86 \%$ digestibility (López et al., 1966). Besides, bird's-foot trefoil produces condensed tannins which are responsible for increase in $18-25 \%$ of protein harnessing (Hedqvist et al., 2000). It does not cause bloat in ruminants as the result of its high contents of condensed tannins and because stable foam is not formed (Fontoura, 2007).

One of the main factors that limit the development of bird's-foot trefoil is weeds, since they compete for essential resources in this process, such as water, light, nutrients and $\mathrm{CO}_{2}$, especially in the crop establishment phase (Ayala \& Carámbula, 2009). In this period, crops are weak competitors due to their slow growth and development (Formoso, 2011). In addition, competition for light may prevent crop establishment from taking place (Ayala \& Carámbula, 2009).

Weed control in these crops is still carried out by mechanical methods, since there are no registered herbicides. However, the use of herbicides that control weeds in pasture is of great interest to the forage sector, mainly in seed production areas (Ferraz \& Felício, 2010). The chemical method enables weeds to be effectively controlled in cultivation rows, application to large areas, high operational productivity and low need for workforce (Oliveira Jr., 2011). Yet, weed control on forage seed production fields is more complex, since, in general, both forage crops and weeds have similar morphophysiological characteristics.

The closer the morphophysiological features of forage species and weeds, the more intense their competition for spatially scarce resources (Pitelli, 1985) and the harder it is to remove weeds by using chemical methods. Thus, since studies of selectivity of herbicides in forage plants are extremely important, they have been carried out in Brazil to study several crops that do not have enough phytosanitary support, such as white clover (Trifolium repens L.) (Machado et al., 2013), pinto peanut (Arachis pintoi Krap. \& Greg.) (Monteiro et al., 2012), alfalfa (Medicago sativa L.) (Ricci et al., 2011; Hijano et al., 2013), cowpea (Vigna unguiculata (L.) Walp.) (Silva et al., 2014), pearl millet (Pennisetum glaucum (L.) R. Brown) (Dias et al., 2015) and grass (Paspalum notatum Flügge and Axonopus compressus (Swartz) Beauv.) (Costa et al., 2010). However, there are no reports of bird's-foot trefoil crops. Therefore, this study aimed at evaluating selectivity of pre-emergent herbicides in bird's-foot trefoil crops.

\section{Materials and Methods}

In order to evaluate selectivity of pre-emergent herbicides in bird's-foot trefoil crops, experiments were carried out in a greenhouse and on a field in the Weed Science Research Group that belongs to the Agricultural Sciences School at the Universidade Federal de Pelotas, located in Capão do Leão, RS, Brazil. In both experiments, the soil was classified as redyellow argisol, whose texture was sandy loam. It belongs to the Pelotas mapping unit (Embrapa, 2013): $\mathrm{pH}$ in water $=5.4$; $\mathrm{CTC}_{\mathrm{pH} 7}=5.8 \mathrm{cmol}_{\mathrm{c}} \mathrm{dm}^{-3}$; organic matter $=1.1 \%$; clay $=15 \%$; class $=4 ; \mathrm{Ca}=2.5 \mathrm{cmol}_{\mathrm{c}} \mathrm{dm}^{-3} ; \mathrm{Mg}=0.9 \mathrm{cmol}_{\mathrm{c}} \mathrm{dm}^{-3} ; \mathrm{Al}=0.1$ $\mathrm{cmol}_{\mathrm{c}} \mathrm{dm}^{-3} ; \mathrm{P}=9.4 \mathrm{mg} \mathrm{dm}^{-3}$ and $\mathrm{K}=61 \mathrm{mg} \mathrm{dm}^{-3}$.

The experiment in the greenhouse was a completely randomized design with five replicates. Experimental units comprised 8-liter plastic plant pots which were filled with $7.0 \mathrm{~kg}$ soil. Eighteen viable bird's-foot trefoil seeds (cultivar 'São Gabriel'), which had previously been inoculated with Mesorhizobium loti (SEMIA 806) in the ratio of 10 to 1, were sown in every experimental unit. Based on the soil analysis, fertility was improved when sowing was carried out by applying $250 \mathrm{~kg} \mathrm{ha}^{-1}$ fertilizer whose formula was 05-30-15 (CQFS, 2016). Treatments were composed of eight pre-emergent herbicides, besides the witness with no herbicide (Table 1). It should be

Table 1. Pre-emergent herbicides under investigation.

\begin{tabular}{|c|c|c|c|}
\hline Mechanisms of action & Chemical group & Active ingredient & $\begin{array}{c}\text { Dose } \\
(\text { (g i.a. ha-1) }\end{array}$ \\
\hline Inhibitor of ALS ${ }^{1}$ & Imidazolinone & Imazethapyr & 100 \\
\hline Inhibitor of ALS & Triazolopirimidines & Diclosulam & 35 \\
\hline Inhibitor of PS $\|^{2}$ & Triazinone & Metribuzin & 480 \\
\hline Inhibitor of cell division & Chloroacetamides & S-metolachlor & 1920 \\
\hline Inhibitors of $4-\mathrm{HPPD}^{5}$ & Isoxazole & Isoxaflutole & 105 \\
\hline
\end{tabular}


highlighted that herbicide doses under investigation were based on maximum doses registered for $\mathrm{RR}^{\circledR}$ soybean crops (Agrofit, 2016).

Treatments were applied on the day bird's-foot trefoil seeds were sown (sow/apply system) with the use of a $\mathrm{CO}_{2}$ pressurized backpack sprayer with fan-like spray tips 110.01, calibrated to apply $120 \mathrm{~L} \mathrm{ha}^{-1}$ herbicide solution. When herbicides were applied, mean air relative humidity (\%), temperature $\left({ }^{\circ} \mathrm{C}\right)$ and wind velocity $\left(\mathrm{m} \mathrm{s}^{-1}\right)$ were $77 \%, 14.6{ }^{\circ} \mathrm{C}$ and $1.4 \mathrm{~m} \mathrm{~s}^{-1}$, respectively. After application and throughout the whole experiment, irrigation was conducted so as to restore water demand and keep humidity close to the field capacity daily.

Phytotoxicity (PHYTO), plant stature, dry mass of the aerial part (DMAP) and dry mass of roots (DMR) were evaluated. Regarding the variable PHYTO, evaluations were carried out $6,12,18$ and 24 days after emergence (DAE) by a percentage scale from 0 to 100 , in which zero (0) corresponds to absence of damage while one hundred (100) corresponds to plant death (Frans \& Crowley, 1986). The variable stature was evaluated 24 DAE in ten plants per replicate by a millimeter ruler, considering the length from the level of the soil to their apexes, with stretched leaf blades.

Concerning variables DMAP and DMR, collection of the aerial part on the level of the soil was carried out 24 DAE; the root system was then washed to separate soil particles. After all collected plant material had been dried in a forced air oven at $60{ }^{\circ} \mathrm{C}$ for $72 \mathrm{~h}$, it was weighed.

In order to reach higher reliability in the selectivity of herbicides under study in the bird's-foot trefoil crop, an experiment with the same treatments was conducted on a field. It was a randomized complete block design with four replicates. Experimental units comprised plots that measured $12.5 \mathrm{~m}^{2}(5 \times 2.5 \mathrm{~m})$. Treatments were also applied with the use of the previously described device. Regarding environmental conditions, air relative humidity was $63 \%$, temperature was $24.4{ }^{\circ} \mathrm{C}$ and wind velocity was $1.0 \mathrm{~m} \mathrm{~s}^{-1}$.

Before sowing, the soil was conventionally prepared, and it was plowed and then harrowed twice. Sowing was carried out by a seed drill for forage, whose working width was $2.5 \mathrm{~m}$ and density was calibrated to distribute $10 \mathrm{~kg} \mathrm{ha}^{-1}$ viable seeds, by releasing and burying them. Base fertilization followed guidelines issued by the manual of fertilization and liming in RS and Santa Catarina (SC) states; yield expectation is $4.0 \mathrm{tha}^{-1}$ dry mass (CQFS, 2016).

Concerning variables under investigation, PHYTO and DMAP were evaluated 24 DAE. The population was quantified by counting bird's-foot trefoil seedlings and by recording the ones that had their first expanded trefoil. The previously described methodology was also used for determining both variables PHYTO and DMAP. Quantification was only carried out at the end of the evaluation period because the emergence of bird's-foot trefoil took place gradually as the result of a dry spell.

Data found by both experiments were evaluated in terms of normality (Shapiro-Wilk test) and homoscedasticity
(Hartley's test) and then submitted to the analysis of variance ( $p \leq 0.05$ ). When statistical significance was found, means were compared by the Duncan's test $(p \leq 0.05)$. Determination of selective pre-emergent herbicides in the crop led to those whose PHYTO were below or equal to $15 \%$ and had not significantly interfered in variables population, stature, DMAP and DMR, by comparison with the witness.

\section{Results and Discussion}

Normality and homoscedasticity tests showed that data transformation was not needed in any experiment. In the case of the experiment carried out in a greenhouse, the analysis of variance showed that the treatments with herbicides affected all variables under study: plant population, PHYTO, stature, DMAP and DMR.

Regarding PHYTO, imazethapyr was more selective than the other herbicides six DAE, since it was the only one that did not differ from the witness (Table 2). In this period, clomazone was the most phytotoxic treatment in the crop, whose phytotoxicity of $89 \%$ was attributed to the symptoms.

Evaluations that were conducted 12, 18 and 24 DAE showed gradual increase in PHYTO when diclosulam, S-metolachlor, clomazone, isoxaflutole and metribuzin (Table 2) were applied. However, flumetsulam, sulfentrazone and imazethapyr led to recovery of phytotoxicity $24 \mathrm{DAE}$; thus, they were the most selective herbicides in the group under investigation.

Symptoms found for clomazone were characterized by intense whitening, as the result of normal development, but with no production of green photosynthetic tissues, which leads to necrosis and seedling death (Oliveira Jr., 2011). In the case of diclosulam, damage was characterized by the fact that hypocotyls of seedlings got purple and stopped growing, but the ones that were in the cotyledon stage were kept. Concerning S-metolachlor, symptoms were characterized by deformation in the first true leaves of seedlings, whereas isoxaflutole led to intense chlorosis in cotyledons; it changed to whitening, a similar process to the one that occurred when clomazone was applied. The other herbicides were

Table 2. Phytotoxicity (PHYTO) of a bird's-foot trefoil crop submitted to application of pre-emergent herbicides $6,12,18$ and 24 days after emergence (DAE). Experiment at greenhouse.

\begin{tabular}{lcccc}
\hline \multirow{2}{*}{ Treatments } & \multicolumn{4}{c}{ Phytotoxicity (\%) } \\
\cline { 2 - 5 } & 6 DAE & 12 DAE & 18 DAE & 24 DAE \\
\hline Witness & $0.0 \mathrm{e}^{2}$ & $0.0 \mathrm{e}$ & $0.0 \mathrm{f}$ & $0.0 \mathrm{e}$ \\
Imazethapyr & $5.8 \mathrm{de}$ & $14.3 \mathrm{~d}$ & $16.5 \mathrm{e}$ & $12.5 \mathrm{~d}$ \\
Diclosulam & $10.6 \mathrm{~cd}$ & $24.8 \mathrm{c}$ & $62.7 \mathrm{c}$ & $97.2 \mathrm{a}$ \\
Flumetsulam & $14.2 \mathrm{c}$ & $15.6 \mathrm{~d}$ & $17.4 \mathrm{e}$ & $9.0 \mathrm{~d}$ \\
S-metolachlor & $13.4 \mathrm{c}$ & $57.7 \mathrm{~b}$ & $80.3 \mathrm{~b}$ & $90.8 \mathrm{~b}$ \\
Clomazone & $89.0 \mathrm{a}$ & $99.6 \mathrm{a}$ & $98.8 \mathrm{a}$ & $100.0 \mathrm{a}$ \\
Isoxaflutole & $8.3 \mathrm{~cd}$ & $55.6 \mathrm{~b}$ & $55.3 \mathrm{~d}$ & $85.2 \mathrm{c}$ \\
Metribuzin & $35.0 \mathrm{~b}$ & $94.6 \mathrm{a}$ & $95.2 \mathrm{a}$ & $100.0 \mathrm{a}$ \\
Sulfentrazone & $8.6 \mathrm{~cd}$ & $13.0 \mathrm{~d}$ & $14.2 \mathrm{e}$ & $11.0 \mathrm{~d}$ \\
C.V.(\%) & 19.5 & 12.1 & 7.2 & 2.9 \\
\hline
\end{tabular}

${ }^{1}$ Days after emergence. ${ }^{2}$ Means with identical letters in a column did not differ by the Duncan's test at $5 \%$ probability. 
characterized by chlorosis in cotyledonary leaves, where metribuzin caused the highest damage.

At the end of the evaluation period (24 DAE), herbicides that met the criterion of selectivity were flumetsulam, sulfentrazone and imazethapyr (Table 2). Both clomazone and metribuzin were the most phytotoxic treatments, since the damage they caused led to seedling death, with no sign of recovery. Regarding diclosulam, S-metolachlor and isoxaflutole, they caused damage that affected crop development, although they did not completely eliminate plant population 24 DAE.

Considering stature, DMAP and DMR, since sulfentrazone reached better results than the other herbicides, it was the most selective one (Table 3 ). It should also be highlighted that this herbicide exhibited better results than the witness in terms of DMAP, even though results of the other variables were similar. The compensatory response of the crop to chemical stress observed for sulfentrazone for DMAP can be attributed due to the activation of enzymatic and nonenzymatic defense mechanisms. Changes in the metabolic routes of species originating from a herbicide spray, with activation of secondary metabolism of the plant (Chuah et al., 2015; Marchezan et al., 2017) induce the defense and overcoming of stress that favor and stimulate their growth (Metlen et al., 2009).

Imazethapyr did not differ from the witness in relation to the accumulation of DMAP, but it reached lower values of stature and DMR than the ones of the witness (Table 3). Values exhibited by flumetsulam did not differ from the ones of imazethapyr. Likewise, S-metolachlor did not differ from isoxaflutole. Low values found for S-metolachlor and isoxaflutole were consistent with the previously reported values of phytotoxicity.

Seedling death resulting from clomazone and metribuzin revealed that neither had any selectivity in the bird's-foot trefoil crop. Besides, low values of stature, DMAP and DMR found as the result of diclosulam application showed that this treatment was not a viable tool in the crop, since these results reflected phytotoxic symptoms (Tables 2 and 3 ).

Table 3. Stature, dry mass of the aerial part (DMAP) and dry mass of roots (DMR) of bird's-foot trefoil plants submitted to application of pre-emergent herbicides 24 days after emergence (DAE). Experiment at greenhouse.

\begin{tabular}{lccc}
\hline \multirow{2}{*}{ Treatments } & $\begin{array}{c}\text { Stature } \\
\text { (cm plant }\end{array}$ & & \multicolumn{2}{c}{ DMAP } & DMR \\
\cline { 3 - 4 } & $4.3 \mathrm{a}^{1}$ & \multicolumn{2}{c}{$\left(\mathrm{mg} \mathrm{plant}^{-1}\right)$} \\
\hline Witness & $3.1 \mathrm{~b}$ & $25.2 \mathrm{~b}$ & $13.2 \mathrm{a}$ \\
Imazethapyr & $0.9 \mathrm{~d}$ & $5.3 \mathrm{bc}$ & $6.1 \mathrm{bc}$ \\
\hline Diclosulam & $3.0 \mathrm{bc}$ & $16.6 \mathrm{c}$ & $7.9 \mathrm{~d}$ \\
Flumetsulam & $2.9 \mathrm{bc}$ & $9.7 \mathrm{de}$ & $5.4 \mathrm{c}$ \\
S-metolachlor & $0.0 \mathrm{e}$ & $0.0 \mathrm{e}$ & $0.0 \mathrm{e}$ \\
Clomazone & $2.4 \mathrm{c}$ & $11.3 \mathrm{~d}$ & $4.2 \mathrm{~cd}$ \\
Isoxaflutole & $0.0 \mathrm{e}$ & $0.0 \mathrm{e}$ & $0.0 \mathrm{e}$ \\
Metribuzin & $4.1 \mathrm{a}$ & $31.1 \mathrm{a}$ & $12.1 \mathrm{a}$ \\
Sulfentrazone & 19.3 & 26.8 & 29.8 \\
\hline C.V.(\%) & & &
\end{tabular}

${ }^{1}$ Means with identical letters in a column did not differ by the Duncan's test at $5 \%$ probability.
Differences in stature, DMAP and DMR values as the result of flumetsulam and sulfentrazone application were not consistent with the similarity found in phytotoxicity. In fact, low values of these morphological variables found after flumetsulam application, by comparison with sulfentrazone, are not always associated with visual symptoms of apparent phytotoxicity, which is known as invisible or hidden phytotoxicity (López Ovejero et al., 2003).

An investigation into forage species Brachiaria brizantha and $B$. decumbens corrobates results found by this study, since it showed that imazethapyr application as a pre-emergent treatment interfered neither in plant stature nor in dry mass negatively, even though it resulted in low phytotoxicity (Rodrigues-Costa et al., 2011). In alfalfa crops, plants submitted to imazethapyr application showed neither phytotoxicity nor decrease in the dry mass of roots and stature; however, there was decrease in the dry mass of the aerial part (Oliveira et al., 1997). Likewise, imazethapyr application as a pre-emergent treatment did not interfere in the accumulation of dry mass of red clover and Egyptian clover plants (Díaz et al., 1992; Espinoza \& Díaz, 1996).

Similar results to the ones found for flumetsulam were observed in alfalfa crops, where plants treated with this herbicide showed moderate phytotoxicity, besides decrease in the dry mass of the aerial part and roots, but there was no decrease in stature (Oliveira et al., 1997). However, in the same crop, flumetsulam was found to be selective at doses of 60 and $120 \mathrm{~g}$ i.a. ha-1; neither phytotoxicity nor decrease in dry biomass per plant was observed (Silva et al., 2001; Silva et al., 2002).

In the experiment that was carried out on a filed, effects of herbicide treatments on plant population, PHYTO and DMAP were found by the analysis of variance. The population of bird's-foot trefoil was negatively affected by the application of clomazone, metribuzin, isoxaflutole, diclosulam, S-metolachlor and flumetsulam, since it decreased in about 98, 92, 83, 63, 48 and $22 \%$, respectively, by comparison with the witness (Table 4). However, application of imazethapyr and sulfentrazone did

Table 4. Plant population, phytotoxicity (PHYTO) and dry mass of the aerial part (DMAP) of a bird's-foot trefoil crop submitted to application of pre-emergent herbicides 24 days after emergence (DAE). Experiment at field.

\begin{tabular}{lccc}
\hline \multicolumn{1}{c}{ Treatments } & $\begin{array}{c}\text { Population } \\
\left(\mathrm{m}^{2}\right)\end{array}$ & $\begin{array}{c}\text { Phytotoxicity } \\
(\%)\end{array}$ & $\begin{array}{c}\text { DMAP } \\
\left(\mathrm{g} \mathrm{m}^{-2}\right)\end{array}$ \\
\hline Witness & $514.6 \mathrm{a}^{2}$ & $0.0 \mathrm{e}$ & $13.8 \mathrm{a}$ \\
Imazethapyr & $505.3 \mathrm{a}$ & $28.3 \mathrm{c}$ & $8.7 \mathrm{c}$ \\
Diclosulam & $191.0 \mathrm{~d}$ & $85.0 \mathrm{~b}$ & $0.9 \mathrm{e}$ \\
Flumetsulam & $402.0 \mathrm{~b}$ & $27.0 \mathrm{c}$ & $8.9 \mathrm{c}$ \\
S-metolachlor & $270.0 \mathrm{c}$ & $93.0 \mathrm{a}$ & $4.5 \mathrm{e}$ \\
Clomazone & $10.0 \mathrm{f}$ & $99.0 \mathrm{a}$ & $0.1 \mathrm{f}$ \\
Isoxaflutole & $88.7 \mathrm{e}$ & $94.3 \mathrm{a}$ & $0.2 \mathrm{f}$ \\
Metribuzin & $42.8 \mathrm{ef}$ & $93.0 \mathrm{a}$ & $0.1 \mathrm{f}$ \\
Sulfentrazone & $509.3 \mathrm{a}$ & $15.0 \mathrm{~d}$ & $10.6 \mathrm{~b}$ \\
C.V.(\%) & 16.7 & 6.9 & 12.1 \\
\hline
\end{tabular}

${ }^{1}$ Days after emergence. ${ }^{2}$ Means with identical letters in a column did not differ by the Duncan's test at $5 \%$ probability. 
not lead to any significant change in the population of bird'sfoot trefoil, by comparison with the witness.

Results of PHYTO found on the field corroborate the ones found in the greenhouse, where the lowest damage was caused by sulfentrazone, flumetsulam and imazethapyr (Table 4). However, it should be emphasized that ALS inhibitors (flumetsulam and imazethapyr) led to PHYTO close to $30 \%$; it was considered high in terms of selectivity (Velini et al., 1995), but these symptoms could be overcome as the crop developed. Since PHYTO was above $85 \%$ in the cases of clomazone, metribuzin, isoxaflutole, S-metolachlor and diclosulam, they were not considered selective in the crop.

Results of DMAP corroborate the ones of phytotoxicity, and values of herbicide treatments were below the ones of the witness (Table 4). Thus, considering the most selective herbicides in the bird's-foot trefoil crop, sulfentrazone, flumetsulam and imazethapyr decreased DMAP in 23, 35 and $37 \%$, respectively. Even when decrease in DMAP was above $20 \%$ for these herbicides, crop development was not affected, since bird's-foot trefoil has slow initial development.

In cowpea crops, sulfentrazone application as a preemergent herbicide exhibited low phytotoxicity to plants and was considered selective in the crops (Fontes et al., 2013). In soybean crops, sulfentrazone application led to low phytotoxicity and decrease in plant stature (Osipe et al., 2014). However, in contrast to results found by this study, sulfentrazone was found to exhibit no selectivity in forage plants 'Estilosantes Campo Grande' (Verzignassi et al., 2005).

A study of alfalfa crop showed that S-metolachlor led to high phytotoxicity and was not considered a good alternative as a pre-emergent treatment (Hijano et al., 2013). In turnip rape crops, results were different from the ones found in bird's-foot trefoil crops, since neither phytotoxicity nor decrease in stature and dry mass was observed in plants (Mascarenhas et al., 2010).

Even though diclosulam was selective in soybean crop, it led to negative effects on plant growth because of visual phytotoxicity and decrease in plant stature (Osipe et al., 2014). Clomazone and metribuzin, which were considered the most toxic treatments in bird's-foot trefoil crops, exhibited similar results when they were applied as pre-emergent herbicides to forage species Panicum maximum, $B$. decumbens and $B$. brizantha (Alves et al., 2002). Studies of turnip rape crops (Mascarenhas et al., 2010) and alfalfa (Oliveira et al., 1997) showed that metribuzin applied as a pre-emergent herbicide resulted in death of all plants.

Effects of pre-emergent herbicides may vary, depending on the type of soil and weather conditions. It has been known that soils with high content of clay and organic matter adsorb herbicide molecules more and tend to mitigate effects of phytotoxicity in crops (Monquero et al., 2008). In addition, soil humidity significantly influences the behavior of these herbicides in weed control (Pereira et al., 2018).

The selective herbicide sulfentrazone and herbicides with intermediate selectivity (imazethapyr and flumetsulam) exhibit broad spectrum weed control for both eudicotyledons and monocotyledons. Main weeds found in bird's-foot trefoil crops are: Urochloa plantaginea (Link) R.D. Webster (marmeladegrass), Digitaria spp. (crabgrass), Ipomoea grandifolia (Dammer) O'Donell (morning glory), Bidens pilosa L. (blackjack), Raphanus sativus L. (radish) and Amaranthus spp. (slender amaranth). These species are satisfactorily controlled by the herbicides, even though radish is not controlled by sulfentrazone. Moreover, control with the use of inhibitors of ALS may be unsatisfactory in areas where resistance has been recorded.

It should be highlighted that results of both experiments refer to the bird's-foot trefoil cultivar in the environment and the type of soil that were previously described. As a result, new studies of herbicide selectivity in different environments and types of soils should be carried out, since such factors may influence plant tolerance to herbicides. Besides, search for new results is highly important to register herbicides to be applied to bird's-foot trefoil crops, an essential tool to minimize problems caused by weeds.

\section{Conclusions}

Results found by both experiments led to the conclusion that sulfentrazone is selective and may be used as a preemergent herbicide in bird's-foot trefoil crops (cultivar 'São Gabriel').

Even though flumetsulam and imazethapyr affected the initial development of the crop, they exhibited satisfactory results, while diclosulam, clomazone, metribuzin, isoxaflutole and S-metolachlor were not selective in the crop.

\section{Acknowledgments}

The authors would like to thank Coordenação de Aperfeiçoamento de Pessoal de Nível Superior - Brasil (CAPES). To Conselho Nacional de Desenvolvimento Científico e Tecnológico (CNPq) for the Research Fellowship of Dr. Dirceu Agostinetto/N.Proc. 308363/2018-3, to the Universidade Federal de Pelotas and to the Programa de Pós-Graduação em Fitossanidade.

\section{Literature Cited}

Agrofit. Sistema de agrotóxicos fitossanitários. http://extranet. agricultura.gov.br/agrofit_cons/principal_agrofit_cons. 25 Oct. 2016.

Alves, E.; Martins, D.; Souza, F.H.D. Seletividade de herbicidas pré-emergentes para gramíneas forrageiras tropicais. Planta Daninha, v.20, n.3, p.457-464, 2002. https://doi.org/10.1590/ S0100-83582002000300017.

Ayala, W.; Carámbula, M. El valor agronómico del gênero Lotus. Uruguai: INIA, 2009. 424p.

Chuah, T.S.; Norhafizah, M.Z.; Ismal, B.S. Evaluation of the biochemical and physiological activity of the natural compound, 2,4-ditertbutylphenol on weeds. Crop \& Pasture Science, v.66, n.2, p.214-223, 2015. https://doi.org/10.1071/CP13386. 
Costa, N.V.; Martins, D.; Rodrigues, A.C.P.; Cardoso, L.A. Seletividade de herbicidas aplicados na grama batatais e na grama São Carlos. Planta Daninha, v.28, n.2, p.365-374, 2010. https://doi. org/10.1590/S0100-83582010000200016.

Comissão de Química e Fertilidade do Solo - CQFS-RS/SC. Manual de calagem e adubação para os estados do Rio Grande do Sul e Santa Catarina. 11.ed. Santa Maria: Sociedade Brasileira de Ciência do Solo, 2016. 376p.

Dias, R.; Gonçalves, C.; Reis, M.; Mendes, K.; Carneiro, G.; Melo, C.; Pereira, A. Seletividade de herbicidas aplicados em pósemergência no milheto. Revista Brasileira de Herbicidas, v.14, n.4, p.348-355, 2015. https://doi.org/10.7824/rbh.v14i4.455.

Díaz, J.; Demanet, R.; Zapata, M. Tolerancia de forrajeras a herbicidas. Agroanálisis, v.98, n.1, p.12-14, 1992.

Espinoza, N.; Díaz, J. Malezas en praderas. In: Ignacio, R.N. (Ed.). Praderas para Chile. Santiago: Instituto de Investigaciones Agropecuarias, 1996. p.345-355.

Food and Agriculture Organization of the United Nations - FAO. Food and Agricultural commodities production. http://faostat.fao.org/ site/569/DesktopDefault.aspx. 08 Mar. 2020.

Ferraz, J.B.S.; Felício, P.E.D. Production systems - an example from Brazil. Meat Science, v.84, n.2, p.238-243, 2010. https://doi. org/10.1016/j.meatsci.2009.06.006.

Flores, R.A.; Dall'agnol, M.; Nabinger, C.; Montardo, D.P. Produção de forragem de populações de azevém anual no estado do Rio Grande do Sul. Revista Brasileira de Zootecnia, v.37, n.7, p.1168-1175, 2008. https://doi.org/10.1590/S1516-35982008000700005.

Fontes, J.; Oliveira, I.; Gonçalves, J. Seletividade e eficácia de herbicidas para cultura do feijão-caupi. Revista Brasileira de Herbicidas, v.12, n.1, p.47-55, 2013. https://doi.org/10.7824/ rbh.v12i1.214.

Fontoura, R. A. Seleção de rizóbios nativos, de solos do Rio Grande do Sul, para Lotus glaber e Lotus subbiflorus. Porto Alegre: Universidade Federal do Rio Grande do Sul, 2007. 83p. Dissertação Mestrado. https://www.lume.ufrgs.br/handle/10183/12427. 17 Feb. 2020.

Formoso, F. Producción de semillas de especies forrajeras. Uruguai: INIA, 2011. 234p.

Frans, R., Crowley, H. Experimental design and techniques for measuring and analyzing plant responses to weed control practices. In: In: Camper, N.D. (Ed.). Research methods in weed science. 3.ed. Champaign: Southern Weed Science Society, 1986. p.29-46.

Hedqvist, H.; Mueller-Harvey, I.; Reed, J.D.; Krueger, C.G.; Murphy, $M$. Characterization of tannins and in vitro protein digestibility of several Lotus corniculatus varieties. Animal Feed Science and Technology, v.87, n.1-2, p.41-56. 2000. https://doi.org/10.1016/ S0377-8401(00)00178-4.

Hijano, N.; Monquero, P.A.; Munhoz, W.S.; Gusmao, M.R. Herbicide selectivity in alfalfa crops. Planta Daninha, v.31, n.4, p.903-918, 2013. https://doi.org/10.1590/S0100-83582013000400017.

Instituto Brasileiro de Geografia e Estatística - IBGE. Censo agropecuário 2017. Resultados definitivos. Brasília: IBGE, 2019. 105p. https:// biblioteca.ibge.gov.br/visualizacao/periodicos/3096/agro_2017_ resultados_definitivos.pdf. 23 Mar. 2020.

López Ovejero, P.M., Christoffoleti, P.J., Nicolai, M., Barela, J.F. Manejo de plantas daninhas na cultura do milho. Fancelli, A. L.; Doudaro-Neto, D. (Eds.). Milho: estratégias de manejo para alta produtividade. Piracicaba: ESALQ, 2003. p.47-79.
López, J.; Prestes, P.J.Q.; Magalhães, E. A curva de crescimento e a composição em carboidratos solúveis, estruturais, lignina e proteína, e a digestibilidade em cornichão. In: Congresso Internacional de Pastagens, 9., 1966, São Paulo. Anais... São Paulo: Alarico, 1966. p.851-857.

Machado, D.; Lustosa, S.B.C.; Baldissera, T.C.; Turok, J.D.N.; Machado, M.; Watzlawick, L.F.; Mendonça, C.G. Pelissari, A. Seletividade de herbicidas em trevo-branco no estádio fenológico de expansão do primeiro trifólio. Ciência Rural, v.43, n.12, p.2132-2138. 2013. https://doi.org/10.1590/S0103-84782013001200002.

Marchezan, M.G.; Avila, L.A.; Agostinetto, D.; Schaedler, C.E.; Langaro, A.C.; Oliveira, C.; Zimmer, M.; Schreiber, F. Morphological and biochemical alterations of paddy rice in response to stress caused by herbicides and total plant submersion. Planta Daninha, v.35, e017139830, 2017. https://doi.org/10.1590/ s0100-83582017350100010.

Mascarenhas, M.H.T.; Lara, J.F.R.; Karam, D.; Araújo, S.G.A.; Ferreira, P.C.; Freire, F.M.; Viana, M.C.V.; Pedrosa; M.W. Nabo forrageiro: seletividade de herbicidas para produção de agroenergia. In: Congresso Brasileiro da Ciência das Plantas Daninhas, 27., Ribeirão Preto. Anais... Ribeirão Preto: Sociedade Brasileira de Plantas Daninhas, 2010. p.2220-2224.

Metlen, K.L.; Aschehoug, E.T.; Callaway, R.M. Plant behavioural ecology: dynamic plasticity in secondary metabolites. Plant, Cell and Environment, v.32, n.6, p.641-653, 2009. https://doi. org/10.1111/j.1365-3040.2008.01910.x.

Monquero, P.A.; Silva, A.C.; Binha, D.P.; Amaral, L.R.; Silva, P.V.; Inacio, E.M.; Mobilidade e persistência de herbicidas aplicados em préemergência em diferentes solos. Planta Daninha, v.26, n.2, p.411417, 2008. https://doi.org/10.1590/S0100-83582008000200018.

Monteiro, F.P.R.; Chagas Junior, A.F.; Reis, M.R.; Santos, G.R.; Chagas, L.F.B. Efeitos de herbicidas na biomassa e nodulação do feijãocaupi inoculado com rizóbio. Revista Caatinga, v.25, n.3, p.4451, 2012. https://periodicos.ufersa.edu.br/index.php/caatinga/ article/view/2550/pdf_8. 17 Feb. 2020.

Oliveira Jr., R.S.; Inoue, M.H. Seletividade de herbicidasparaculturas e plantas daninhas. In: Oliveira Jr., R.S.; Consttantin, J.; Inoue, M.H. (Eds.). Biologia e manejo de plantas daninhas. Curitiba: Omnipax, 2011. p.243-262.

Oliveira, P.P.A; Santos, P.M.; Corsi, M.; Filho, R.V.; Díaz, M. Estudos dos efeitos de fitotoxicidade provenientes do uso de herbicidas no estabelecimento e em culturas estabelecidas de alfafa. Revista Brasileira de Zootecnia, v.26, n.1, p.19-26, 1997.

Osipe, J. B.; Oliveira JR., R.S.; Constantin, J.; Biffe, D.F.; Rios, F.A.; Franchini, L.H.M.; Gheno, E.A.; Raimondi, M.A. Seletividade de aplicações combinadas de herbicidas em pré e pós-emergência para a soja tolerante ao glyphosate. Bioscience Journal, v.30, n.3, p.623-631, 2014. http://www.seer.ufu.br/index.php/ biosciencejournal/article/view/18042. 03 Mar. 2020.

Pereira, G.A.M.; Rodrigues, D.A.; Fonseca, L.A.B.V.; Passos, A.B.J.; Silva, M.R.F.; Silva, D.V.; Silva, A.A. Sorption and desorption behavior of herbicide clomazone in soils from Brazil. Bioscience Journal, v.34, n.6, p.1496-1504, 2018. https://doi.org/10.14393/ BJ-v34n6a2018-39492.

Pitelli, R.A., Interferências de plantas daninhas em culturas agrícolas. Informe Agropecuário, v.11, n.129, 1985. p.16-24. 
Ricci, T.T.; Piccinin, G.G.; Dan, L.G.M.; BarroS, A.L.L.; Carrijo, M.S.; Ortiz, A.H.T. Avaliação de seletividade dos herbicidas chlorimuron-ethyl e nicosulfuron aplicados em pós-emergência na cultura da alfafa. Revista Brasileira de Herbicidas, v.10, n.1, p.20-28, 2011. https:// doi.org/10.7824/rbh.v10i1.92.

Rodrigues-Costa, A.C.P.; Martins, D.; Costa, N.V.; Campos, C.F.; Martins, C.C.; Pereira, M.R.R.; Silva, J.I.C. Seletividade de herbicidas aplicados em pré-emergência em gramíneas forrageiras. Planta Daninha, v.29, n.3, p.625-633, 2011. https://doi.org/10.1590/ S0100-83582011000300017.

Silva, K.S.; Freitas, F.C.L.; Silveira, L.M.; Linhares, C.S.; Carvalho, D.R.; Lima, M.F.P. Eficiência de herbicidas para a cultura do feijãocaupi. Planta Daninha, v.32, n.1, p.197-205, 2014. https://doi. org/10.1590/s0100-83582014000100022.
Silva, W.; Vilela, D.; Ferreira, L.R.; Ferreira, R.P.; Ferreira, F.A. Tolerância da alfafa (Medicago sativa L.) a diferentes herbicidas aplicados em pré-emergência e pós-emergência. Revista Ceres, v.48, n.278, p.415-425, 2001. http://www.ceres.ufv.br/ojs/index. php/ceres/article/view/2714. 10 Mar. 2020.

Silva, W.; Vilela, D.; Ferreira, R.P.; Pereira, A.V.; Cobucci, T. Herbicidas na cultura da alfafa. Revista Ceres, v.49, n.284, p.405-418, 2002. http://www.ceres. ufv.br/ojs/index.php/ceres/article/view/2827. 12 Mar. 2020.

Veline, E.D.; Osipe, R.; Gazziero, D.L.P. Procedimentos para instalação, avaliação e análise de experimentos com herbicidas. Londrina: SBCPD, 1995. 42p.

Verzignassi, J.; Pereira, F.; Fernandes, C.; Vida, J. Seletividade de herbicidas a Stylosanthes capitata e a S. macrocephala. Revista Brasileira de Herbicidas, v.4, n.3, p.59-67, 2005. https://doi.org/10.7824/rbh.v4i3.37. 